\title{
Use of complementary and alternative medicine by a sample of Turkish primary headache patients
}

\author{
Primer baş ağrrss olan Türk hastalarda tamamlayıcı ve \\ alternatif tedavi yöntemlerinin kullanımı
}

\author{
Başak KARAKURUM GÖKSEL, ${ }^{1}$ Özlem COŞKUN, ${ }^{2}$ Serap UCLER, ${ }^{2}$ \\ Mehmet KARATAS, ${ }^{1}$ Aynur OZGE, ${ }^{3}$ Secil OZKAN ${ }^{4}$
}

\begin{abstract}
Summary
Objective: Complementary and alternative medicine (CAM) is increasingly being used as adjunctive treatment in primary headache syndromes in many countries. In the Turkish population, no epidemiologic data have been reported about awareness and usage of these treatments in patients with headache.

Methods: One hundred and ten primary headache patients attending three headache clinics completed a questionnaire regarding their headaches, the known modalities and the use and effect of CAM procedures for their headaches.

Results: The mean age of the patients was $34.7 \pm 9.6$ years $(32.8-36.5)$. Almost two-thirds of patients had completed high school and university, and one-third of patients were housewives. Migraine without aura (45.5\%) was the most frequently diagnosed type of headache followed by migraine with aura (19.1\%) and tension-type headache (18.2\%). In $43.6 \%$ of the patients, headache frequency was 5-10 per month. The most frequently known CAM modalities were massage (74.5\%), acupuncture $(44.5 \%)$, yoga $(31.8 \%)$, exercise $(28.2 \%)$, psychotherapy $(25.5 \%)$, and rosemary $(23.6 \%)$. The most frequently used CAM treatments were massage (51\%) and exercise (11\%). Only massage was reported to be beneficial in one-third of the primary headache patients; the other modalities were not.

Conclusion: Our findings suggest that the subgroup of primary headache patients in Turkey seek and use alternative treatments, frequently in combination with standard treatments. Neurologists should become more knowledgeable regarding CAM therapies; further randomized and controlled clinical researches with large sample sizes are needed.
\end{abstract}

Key words: Acupuncture; complementary and alternative medicine; headache; migraine.

\section{Özet}

Amaç: Tamamlayıcı ve alternatif tıp yöntemleri (TAT), primer baş ağrısı tedavisi için pek çok ülkede kullanılmaktadır. Türk popülasyonunda, primer baş ăgrılarında TAT yöntemlerinin bilinirlĭgi, kullanımı ve yararına yönelik epidemiyolojik veri bulunmamaktadir.

Gereç ve Yöntem: Ü̧̧ baş ağrısı merkezine başvuran 110 primer baş ağrilı olguya baş ağrısında kullanilan TAT yöntemlerinin bilinirliği, kullanımı ve yararlanılmasına ilişkin sorular içeren formlar verilerek yanıtlanması istendi.

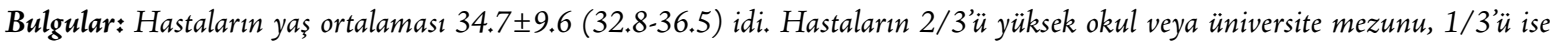
ev hanımıydı. Olgularda en sık aurasız migren (\%45.5), daha az sıklikla auralı migren (\%19.1) ve gerilim tipi baş ă̆rısı (\%18.2) saptandı. Hastaların \%43.6'sında baş ăgrısı sıklı̆̆ı 5-10/ay bulunmuştur. En sık bilinen modaliteler sırasıyla masaj (\%74.5), akupunktur (\%44.5), yoga (\%31.8), egzersiz (\%28.2), psikoterapi (\%25.5) ve biberiye kullanımı (\%23.6) idi. En sik kullanılan TAT yöntemi masaj (\%51) ve egzersiz (\%11) olarak saptandı. Bununla beraber olguların 1/3’ü masajdan fayda gördüğ̈̈n̈̈ belirtti.

Sonuç: Bizim verilerimiz primer baş ağrılı Türk hastaların, standart tedavilere ek olarak alternatif tedavi arayışları olduğunu ve bu tedavilerden en azından birkaçını kullandıkların göstermiştir. Nörologların bu konuda bilgilerini artırmaları yanında, bu konuda yapılacak büyük grupları içeren randomize çalı̧̧malara ibtiyaç duymaktadır.

Anahtar sözcükler: Akupunktur; alternatif ve tamamlayıcı tedaviler; baş ağrısı; migren.

\footnotetext{
'Department of Neurology, Baskent University Faculty of Medicine, Adana Training and Medical Research Center, Adana; ${ }^{2}$ Department of Neurology, The Ministry of Health Ankara Hospital, Ankara;

${ }^{3}$ Department of Neurology, Mersin University Faculty of Medicine, Mersin;

${ }^{4}$ Department of Public Health, Gazi University Faculty of Medicine, Ankara, Turkey

'Başkent Üniversitesi Tıp Fakültesi, Adana Uygulama ve Araştırma Merkezi, Nöroloji Bilim Dalı, Adana;

${ }^{2}$ Sağlık Bakanlığı Adana Uygulama ve Araştırma Merkezi, Nöroloji Kliniği, Ankara;

${ }^{3}$ Mersin Üniversitesi Tıp Fakültesi, Nöroloji Anabilim Dalı, Mersin;

${ }^{4}$ Gazi Üniversitesi Tıp Fakültesi, Halk Sağlığı Anabilim Dalı, Ankara

Submitted (Başvuru tarihi) 31.03.2012 Accepted after revision (Düzeltme sonrası kabul tarihi) 13.12.2012
}

Correspondence (İletişim): Dr. Başak Karakurum Göksel. Başkent Üniversitesi, Adana Uygulama ve Araştırma Merkezi, Nöroloji Bilim Dalı, Dadaloğlu Mah., 39 . Sok., 01250 Adana, Turkey. Tel: +90 - 322 - 3272727 / 1090 e-mail (e-posta): bkarakurum@hotmail.com 


\section{Introduction}

According to International Headache Society (IHS), the primary headache disorders-those not associated with an underlying pathology-include migraine, tension-type and cluster headache. ${ }^{[1]}$ The lifetime prevalence for migraine is $11 \%$ and tension-type headache is $78 \%$. Cluster headaches represent a smaller percentage of primary headaches. Although many patients with headache receive positive benefit from conventional pharmacological treatments, many others do not benefit sufficiently or experience adverse effects from these treatments. For that reason these patients usually seek complementary and/or alternative medical (CAM) treatments in all over the world. ${ }^{[2]}$

The concept of alternative medicine started to become popular towards the end of the 1970s. In recent years, it has been common practice to use CAM in the treatment of headache, alone and in combination with drugs. These medicines include an extensive scope of medicine forms, such as herbal therapy, religious belief and healing with hands (acupuncture, etc.). ${ }^{[3-5]}$ The US National Center for Complementary and Alternative Medicine defines CAM as a group of diverse medical and health care systems, practices, and products that are not presently considered to be part of conventional medicine. Although there is increasing evidence for the efficacy and tolerability of some CAM approaches in the management of headache disorders, the majority of CAM therapies still remain to be evaluated in controlled prospective clinical trials. ${ }^{[6-8]}$

CAM therapies are already widely used in many countries. For example, in different studies, $42 \%$ of the general population in the USA, $48 \%$ in Australia, $20 \%$ in the UK, and $11.6 \%$ in Italy were found to have had recourse to CAM at least once in previous year. ${ }^{[9-11]} 29-40 \%$ of patients in Italian headache clinics, $81.7 \%$ of patients in German headache clinics, $85 \%$ of patients in American headache clinics had used CAM therapies. In parallel with the prevalence of CAM usage around the world, there is also increasing interest in these methods in Turkey. [12-17] In general, although CAM therapies are not recommended by regular physicians in Turkey, most of the patients who have not benefit from conven- tional medicine treatments seek alternative therapy from CAM practitioner or friends and relatives rather than healthcare professionals or neurologists. To our knowledge, no study to date has specifically investigated the use of CAM in patients suffering from headache in Turkey.

The aim of this study was therefore to investigate: (1) rates of CAM use in a clinical population of patients with primary headache diagnosed in accordance with the current IHS criteria, (2) whether the patients had heard the names of CAM (3) if the patients was used whether the patients benefited from CAM use, if they had used CAM.

\section{Materials and Methods}

The study population consisted of 110 patients attending the outpatient headache clinic in three department of neurology which were Baskent University Adana Teaching and Medical Center, The Ministry of Health Ankara Hospital and Mersin University School of Medicine. Criteria for selection included a diagnosis of primary headache according to IHS. One hundred ten consecutive patients had a face-to-face interview conducted by one of the neurologists.

Demographic data, including age, gender, sex, marital status, educational level, employment status were recorded. A detailed clinical history was collected from each patient and a physical examination was performed. For each individual, age, sex, migraine history, number of years with daily headaches, headache pain intensity, and use of acute medication were recorded. All patients were asked to keep a daily headache diary in which they described the location and intensity of head pain; the presence of nausea, vomiting, photophobia, or phonophobia; and whether the pain worsened with routine daily activity. The numbers of days per month with headache were also recorded. Primary headaches were diagnosed according to criteria of IHS in $2004 .^{[1]}$

A list of 35 different CAM treatments and modalities with potential effects on pain was recorded (Table 1). The patients were given a list of different CAM treatments and were asked the following 
Table 1. Various techniques of CAM presented to the patients

Massage
Therapeutic touch
Chiropractic
Reflexology
Exercise
Color/art therapy
Dance therapy
Music-sound therapy
Psychodrama
Vitamins/nutritional supplements
Detoxification
Coenzyme Q10
Riboflavin
Magnesium
Ginger
Rosemary
Chrysanthemum
Acupuncture
Ayurveda
Tibetian medicine
Tai Chi
Yoga
Mediation
Relaxation
Biofeedback
Pight treatment life therapy
Hagnetic field therapy
Hyotherapy
Hoxygen therapy

questions: (a) which methods were familiar to them as potential therapeutic interventions, (b) which methods they had tried, and (c) what the results were.

For the statistical analysis, a chi-square test was used to compare the socio-demographic and clinical data with the pattern of responses. A p-value of less than 0.05 was used as the criterion for significance.

\section{Results}

One hundred and ten consecutive new patients with primary headache were evaluated. The sociodemographic characters of the patients are set out in Table 2. The headache characteristics and patterns of the study group were summarized in Table 3.

The mean age of the patients was $34.7 \pm 9.6$ years (32.8-36.5). The corresponding sex distributions (male/female) were 15/95. Most of patients had completed high school and university (65.5\%). $39.1 \%$ of patients were housewives.

Migraine without aura (45.5\%) was the most frequently diagnosed type of headache followed by migraine with aura $(19.1 \%)$ and tension type headache $(18.2 \%)$. In the $43.6 \%$ of the patients, headache frequency was 5-10 per month.

The respondents were asked to indicate their use of an extensive list of complementary therapies given in Table 1. Patients could also indicate their use of any CAM therapy not included in the list. The

Table 2. The socio-demographic characters of patients

\begin{tabular}{lcc}
\hline Variable & $\mathbf{n}$ & \% \\
\hline Age (years) & $34.7 \pm 9.6$ & $32.8-36.5)$ \\
Female & 95 & 86.4 \\
Male & 15 & 13.6 \\
Education & & \\
$\quad$ University/postgraduate & 43 & 39.1 \\
$\quad$ High school & 29 & 26.4 \\
Middle school & 7 & 6.4 \\
Primary school & 20 & 18.2 \\
Illiterate & 11 & 10.0 \\
Employment status & & \\
$\quad$ Housewife & 43 & 39.1 \\
Teacher & 5 & 4.5 \\
Officer & 26 & 23.5 \\
Self employed & 12 & 10.9 \\
Architect & 5 & 4.5 \\
Nurse & 4 & 2.7 \\
Doctor & 8 & 7.3 \\
Engineer & 1 & 0.9 \\
Technician & 3 & 2.7 \\
\hline
\end{tabular}


Table 3. The headache characteristics and patterns of the patients

\begin{tabular}{lcc}
\hline & $\mathbf{n}$ & \% \\
\hline Headache subtype & & \\
$\quad$ Migraine without aura & 50 & 45.5 \\
Migraine with aura & 21 & 19.1 \\
Chronic tension type headache & 10 & 9.1 \\
Episodic tension type headache & 10 & 9.1 \\
Chronic cluster headache & 1 & 0.9 \\
Episodic cluster headache & 1 & 0.9 \\
Chronic migraine & 5 & 4.5 \\
Tension type headache+migraine without aura & 12 & 10.9 \\
Frequency of pain (headache days/month) & & \\
1-4 days / month & 12 & 10.9 \\
5-10 days / month & 48 & 43.6 \\
11-15 days / month & 25 & 22.7 \\
16-30 days / month & 25 & 22.7 \\
\hline
\end{tabular}

most known CAM procedure was massage therapy $(74.5 \%)$ followed by acupuncture $(44.5 \%)$, yoga (31.8\%), exercise $(28.2 \%)$, and rosemary $(26.2 \%)$. The most common CAM method used by the patients was massage therapy (51\%) followed by exercise (10\%) and rosemary (10\%). The most effective CAM treatment modality was massage $(33.6 \%)$ followed by rosemary (7.3\%), and exercise $(6.4 \%)$. The other findings are summarized in Table 4.

We also compared with awareness of the procedures by the patients according to the frequency of the headache. There was no statistically significant difference between headache frequency and all CAM procedures. The headache types (migraine, tension type headache, cluster headache, medication overuse headache and combined headache) were compared awareness, usage of the method and if it benefit or not. There was no statistically significance between headache types and knowledge of CAM modalities except from vitamin and nutritional treatment. Although migraine group knows vitamin and nutritional treatment, there was also no statistically relationship between headache types of patients and usage and effectiveness of the CAM methods.

On the other hand, we also compared the awareness of the CAM procedures by the patients according to the education status. Although patients with university or postgraduate degree know ayurveda, yoga, meditation, and relaxation treatment modalities $(\mathrm{p}<0.05)$, there was no statistically significant difference between education status and usage and benefit of all CAM procedures.

\section{Discussion}

Complementary and alternative medicine (CAM) is increasingly common in the treatment of primary headache disorders despite lack of evidence for efficacy in most modalities in USA and Europe over the past few decades. ${ }^{[4]}$ Although there are a few studies about the use of CAM in cancer, asthma, diabetes mellitus and general population in Turkey, there has not been any prevalence study about the CAM procedures in primary headache patients so far. ${ }^{[12-17]}$ This study has provided the first information about the awareness, use and benefits of the CAM procedures in primary headache patients in Turkey.

In our study group, most patients suffered from migraine $(69.1 \%)$. This proportion is not representing headache prevalence in Turkish population. It is probably related to the characteristics of the headache outpatient clinics. Migraine is the most common headache type in our headache departments. These proportions are similar to Gaul et al's. study. The proportion of the tension type headache patients was lower (18.2\%) like as Gaul et al. study. Probably tension type headache patients are treated 
Table 4. CAM treatments known (left) and used (middle) by patients and efficacy (right)

\begin{tabular}{|c|c|c|c|c|c|c|}
\hline & \multicolumn{2}{|c|}{ Known } & \multicolumn{2}{|c|}{ Tried } & \multicolumn{2}{|c|}{ Perceived usefulness } \\
\hline & $n$ & $\%$ & $\mathbf{n}$ & $\%$ & $\mathbf{n}$ & $\%$ \\
\hline Massage & 82 & 74.5 & 57 & 51 & 37 & 33.6 \\
\hline Therapeutic touch & 1 & 0.9 & 0 & 0 & 0 & 0 \\
\hline Chiropractic & 2 & 1.8 & 0 & 0 & 0 & 0 \\
\hline Reflexology & 5 & 4.5 & 0 & 0 & 0 & 0 \\
\hline Exercise & 31 & 28.2 & 12 & 10.9 & 7 & 6.4 \\
\hline Color/art therapy & 5 & 4.5 & 1 & 0.9 & 1 & 0.9 \\
\hline Dance therapy & 7 & 6.4 & 2 & 1.8 & 2 & 1.8 \\
\hline Music-sound therapy & 11 & 10 & 2 & 1.8 & 2 & 1.8 \\
\hline Psychodrama & 9 & 8.2 & 0 & 0 & 0 & 0 \\
\hline Vitamins/nutritional supplements & 4 & 3.6 & 0 & 0 & 0 & 0 \\
\hline Detoxification & 4 & 3.6 & 0 & 0 & 0 & 0 \\
\hline Coenzyme Q10 & 1 & 0.9 & 0 & 0 & 0 & 0 \\
\hline Riboflavin & 0 & 0 & 0 & 0 & 0 & 0 \\
\hline Magnesium & 13 & 11.8 & 3 & 2.7 & 2 & 1.8 \\
\hline Ginger & 18 & 16.4 & 7 & 6.4 & 5 & 4.5 \\
\hline Rosemary & 26 & 23.6 & 11 & 10 & 8 & 7.3 \\
\hline Chrysanthemum & 5 & 4.5 & 0 & 0 & 0 & 0 \\
\hline Acupuncture & 49 & 44.5 & 5 & 4.5 & 2 & 1.8 \\
\hline Ayurveda & 9 & 8.2 & 0 & 0 & 0 & 0 \\
\hline Tibetian medicine & 5 & 4.5 & 0 & 0 & 0 & 0 \\
\hline Tai Chi & 9 & 8.2 & 0 & 0 & 0 & 0 \\
\hline Yoga & 35 & 31.8 & 1 & 0.9 & 0 & 0 \\
\hline Meditation & 1 & 0.9 & 0 & 0 & 0 & 0 \\
\hline Relaxation & 18 & 16.4 & 1 & 0.9 & 1 & 0.9 \\
\hline Biofeedback & 1 & 0.9 & 0 & 0 & 0 & 0 \\
\hline Light treatment & 11 & 10 & 0 & 0 & 0 & 0 \\
\hline Psychotherapy & 28 & 25.5 & 1 & 0.9 & 1 & 0.9 \\
\hline Past life therapy & 3 & 2.7 & 0 & 0 & 0 & 0 \\
\hline Magnetic field therapy & 5 & 4.5 & 0 & 0 & 0 & 0 \\
\hline Aromatherapy & 11 & 10 & 0 & 0 & 0 & 0 \\
\hline Hydrotherapy & 8 & 7.3 & 0 & 0 & 0 & 0 \\
\hline Support groups & 3 & 2.7 & 0 & 0 & 0 & 0 \\
\hline Hypnotherapy & 23 & 20.9 & 0 & 0 & 0 & 0 \\
\hline Cold therapy & 12 & 10.9 & 3 & 2.7 & 3 & 2.7 \\
\hline Hyperbaric oxygen therapy & 8 & 7.3 & 0 & 0 & 0 & 0 \\
\hline
\end{tabular}

by family physician, general neurology outpatient clinics, or they do not take treatment because pain is not severe. ${ }^{[5]}$

The study demonstrates that relatively high proportion of headache patients know, but not frequently use the CAM therapies. Almost $74.5 \%$ of primary headache patients interviewed had known massage, and $51 \%$ of the patients used massage therapy. Only $33.6 \%$ patients had got benefit from massage. This percentage is similar to Rossi et al. study. ${ }^{[4]}$ Although the most frequently used CAM treatments included acupuncture, followed by massage and relaxation techniques in the literature, the massage was found 
the most popular CAM therapy in our study ${ }^{[4,5]}$ It is known that massage is effective in adults for chronic low back pain and chronic neck pain, knee osteoarthritis, fibromyalgia, myofascial pain syndrome, and premenstrual syndrome, and headache,. But there are a few studies about effectiveness of the massage therapy for migraine and tension type headache. ${ }^{[18,19]}$

Although acupuncture uses widely in China and other Far Eastern countries, it did not gain acceptance in the Western countries until recently. In the Western world, acupuncture is regarded as a form of alternative or complementary medicine. ${ }^{[20]}$ Although Turkey is relatively closer to the eastern countries, this method is still not widely used in Turkey. There are a few studies about acupuncture usage for therapy in Turkish patients. ${ }^{[21,22]}$ There was also no study about effectiveness or usage of the acupuncture for headache in Turkey. However, in our study, we found that the acupuncture therapy is known in $44.5 \%$ of our patients, but its usage is very low (4.5\%), and its effectiveness is $1.8 \%$. Recently, the acupuncture treatment is also frequently used in different western countries for headache. Germany people has mostly used acupuncture for headache, Italian people followed them. American people also know and use this method. On the other hand, while the mechanism of acupuncture treatment is not fully understood, several theories have been hypothesized regarding pathogenesis such as control of pain perception, serotonergic and antiinflammatory effect. ${ }^{[4,5,23,24]}$

We also found that exercise was the frequently used by our headache patients similar to proportion in USA. There are some data on the effects of aerobic exercise in migraine and tension type headache patients. The aerobic exercise is found effective in reduction of the self-rated migraine pain intensity in few reports. ${ }^{[25,26]}$

Interestingly, the rosemary (rosemarinus officinalis) has also been used frequently in migraine patients in Turkey different from the other countries. Although the rosemary therapy is known in $23.6 \%$ of patients, tried in $10 \%$, and benefited in $7.3 \%$ of headache patients in Turkey, we can not find any literature knowledge about rosemary effect on headache. In folk medicine, rosemary is used in oral administra- tion to relief renal colic and dysmenorrhea and as antispasmodic. It is shown antinociceptive effect of rosmarinus officinalis in experimental models in rodents. Although there are lots of literatures about rosemary usefulness in cancer patients, ${ }^{[27,28]}$ there is no scientific evidence about rosemary. Despite everything, Turkish people believe that it has benefit for migraine.

Except from massage, acupuncture, yoga, exercise, rosemary, other therapies has not well known by Turkish patients. For example therapeutic touch (0.9\%), chiropractic (1.8\%), coenzyme Q10 $(0.9 \%)$, riboflavin $(0)$, meditation $(0.9 \%)$, biofeedback $(0.9 \%)$ were not well known. These methods are also not popular in Europe but chiropractic, therapeutic touch, herbs, meditation and biofeedback are frequently used in USA. ${ }^{[2]}$

Recently, in the EFNS guideline on the treatment of tension-type headache (2010), it is pointed out that some CAM treatments such as electromyography biofeedback, cognitive-behavioral therapy, relaxation training, physical therapy and acupuncture may be valuable options for patients with frequent tension-type headache, but there is no robust scientific evidence for efficacy. ${ }^{[30]}$

In conclusion, our study confirms that CAM is also widely used among primary headache patients in Turkey, mostly in combination with standard treatments. Known of CAM treatments in our population was reported by the majority of patients. Most frequently known CAM modalities are massage (74.5\%), acupuncture (44.5\%), yoga $(31.8 \%)$, exercise $(28.2 \%)$, psychotherapy $(25.5 \%)$, and rosemary $(23.6 \%)$. Most frequently used CAM treatments were massage (51\%) and exercise (11\%). However, it is reported that only massage has benefit in one third of primary headache patients, but others are not. With the increasing demand and usage of CAM by the general public, it is vital that healthcare professionals can make informed decisions when advising or referring their patients who wish to use CAM.

There were a number of limitations in the present study. First, a limited sample size limits its power. Second, there is no standard procedure of CAM 
modalities. Thus, large sample size, randomized, controlled trials are needed in the future for more definitive results regarding CAM treatments in primary headache.

\section{Conflict-of-interest issues regarding the author- ship or article: None declared.}

\section{Peer-rewiew: Externally peer-reviewed.}

\section{References}

1. Headache Classification Subcommittee of the International Headache Society. The International Classification of Headache Disorders: 2nd edition. Cephalalgia 2004;24 Suppl 1:9160.

2. Crawford CC, Huynh MT, Kepple A, Jonas WB. Systematic assessment of the quality of research studies of conventional and alternative treatment(s) of primary headache. Pain Physician 2009;12(2):461-70.

3. Rossi $P$, Di Lorenzo G, Faroni J, Malpezzi MG, Cesarino F, Nappi G. Use of complementary and alternative medicine by patients with chronic tension-type headache: results of a headache clinic survey. Headache 2006;46(4):622-31. CrossRef

4. Rossi P, Di Lorenzo G, Malpezzi MG, Faroni J, Cesarino F, Di Lorenzo $C$, et al. Prevalence, pattern and predictors of use of complementary and alternative medicine (CAM) in migraine patients attending a headache clinic in Italy. Cephalalgia 2005;25(7):493-506. CrossRef

5. Gaul C, Eismann R, Schmidt T, May A, Leinisch E, Wieser T, et al. Use of complementary and alternative medicine in patients suffering from primary headache disorders. Cephalalgia 2009;29(10):1069-78. CrossRef

6. Eisenberg DM, Davis RB, Ettner SL, Appel S, Wilkey S, Van Rompay $M$, et al. Trends in alternative medicine use in the United States, 1990-1997: results of a follow-up national survey. JAMA 1998;280(18):1569-75. CrossRef

7. Lambert TD, Morrison KE, Edwards J, Clarke CE. The use of complementary and alternative medicine by patients attending a UK headache clinic. Complement Ther Med 2010;18(3-4):128-34. CrossRef

8. Sun-Edelstein C, Mauskop A. Alternative headache treatments: nutraceuticals, behavioral and physical treatments. Headache 2011;51(3):469-83. CrossRef

9. MacLennan AH, Wilson DH, Taylor AW. Prevalence and cost of alternative medicine in Australia. Lancet 1996;347(9001):56973. CrossRef

10. Kaptchuk TJ, Eisenberg DM. The persuasive appeal of alternative medicine. Ann Intern Med 1998;129(12):1061-5. CrossRef

11. Ernst $E$, White $A$. The $B B C$ survey of complementary medicine use in the UK. Complement Ther Med 2000;8(1):32-6. CrossRef

12. Gözüm S, Tezel A, Koc M. Complementary alternative treatments used by patients with cancer in eastern Turkey. Cancer Nurs 2003;26(3):230-6. CrossRef

13. Unsal A, Gözüm S. Use of complementary and alternative medicine by patients with arthritis. J Clin Nurs 2010;19(78):1129-38. CrossRef

14. Araz N, Bulbul S. Use of complementary and alternative medicine in a pediatric population in southern Turkey. Clin Invest Med 2011;34(1):21-9.

15. Kav T. Use of complementary and alternative medicine: a survey in Turkish gastroenterology patients. BMC Complement Altern Med 2009;9:41. CrossRef

16. Karakurum B, Karaalin O, Coskun O, Dora B, Uçler S, Inan L. The 'dry-needle technique': intramuscular stimulation in tension-type headache. Cephalalgia 2001;21(8):813-7. CrossRef

17. Ucler S, Coskun O, Inan LE, Kanatli Y. Cold Therapy in Migraine Patients: Open-label, Non-controlled, Pilot Study. Evid Based Complement Alternat Med 2006;3(4):489-93. CrossRef

18. Fernández-de-Las-Peñas $C$, Alonso-Blanco $C$, Cuadrado $M L$, Miangolarra JC, Barriga FJ, Pareja JA. Are manual therapies effective in reducing pain from tension-type headache?: a systematic review. Clin J Pain 2006;22(3):278-85. CrossRef

19. Chaibi A, Tuchin PJ, Russell MB. Manual therapies for migraine: a systematic review. J Headache Pain 2011;12(2):12733. crossRef

20. Rabinstein AA, Shulman LM. Acupuncture in clinical neurology. Neurologist 2003;9(3):137-48. CrossRef

21. Sahin N, Ozcan E, Sezen K, Karatas O, Issever H. Efficacy of acupunture in patients with chronic neck pain--a randomised, sham controlled trial. Acupunct Electrother Res 2010;35(1-2):17-27. CrossRef

22. Gülcü N, Bulut S. Content analysis of websites directed to low back pain. Agri 2010;22(2):68-72.

23. von Peter S, Ting W, Scrivani S, Korkin E, Okvat H, Gross M, et al. Survey on the use of complementary and alternative medicine among patients with headache syndromes. Cephalalgia 2002;22(5):395-400. CrossRef

24. Herman PM, Craig BM, Caspi O. Is complementary and alternative medicine (CAM) cost-effective? A systematic review. BMC Complement Altern Med 2005;5:11. CrossRef

25. Busch V, Gaul C. Exercise in migraine therapy--is there any evidence for efficacy? A critical review. Headache 2008;48(6):890-9. CrossRef

26. Darabaneanu $S$, Overath $C H$, Rubin $D$, Lüthje $S$, Sye W, Niederberger $\mathrm{U}$, et al. Aerobic exercise as a therapy option for migraine: a pilot study. Int J Sports Med 2011;32(6):455-60.

27. González-Trujano ME, Peña El, Martínez AL, Moreno J, Guevara-Fefer $P$, Déciga-Campos $M$, et al. Evaluation of the antinociceptive effect of Rosmarinus officinalis L. using three different experimental models in rodents. J Ethnopharmacol 2007;111(3):476-82. CrossRef

28. al-Sereiti MR, Abu-Amer KM, Sen P. Pharmacology of rosemary (Rosmarinus officinalis Linn.) and its therapeutic potentials. Indian J Exp Biol 1999;37(2):124-30.

29. Nestoriuc Y, Martin A. Efficacy of biofeedback for migraine: a meta-analysis. Pain 2007;128(1-2):111-27. CrossRef

30. Bendtsen L, Evers S, Linde M, Mitsikostas DD, Sandrini G, Schoenen J; EFNS. EFNS guideline on the treatment of tension-type headache - report of an EFNS task force. Eur J Neurol 2010;17(11):1318-25. 